\title{
Potrashkova L. \\ DEVELOPMENT OF THE APPROACH TO MODELING THE INFLUENCE OF THE EXTERNAL SOCIAL CAPITAL OF THE ENTERPRISE ON THE DECISIONS OF ITS STAKEHOLDERS
}

\begin{abstract}
Запропоновано підхід до імітащійного моделювання впливу зовнішнього соціального капіталу підприємства на його діяльність на основі моделювання прочесу прийняття рішень стейкхолдерами цього підприємства. Даний підхід передбачає побудову формалізованих задач прийняття рімень, що описують ситуащї вибору, в яких знаходяться стейкхолдери, та налаштуванні параметрів цих задач в залежності від певних характеристик відносин між стейкхолдерами та аналізованим підприємством.
\end{abstract}

Kлючові слова: зовнішній соціальний капітал підприємства, відносини підприємства зі стейкхолдерами, очікування стейкхолдерів, моделювання рімень стейкхолдерів.

\section{Introduction}

Social capital is therefore called capital that it has the ability to make profit to its owner. So, the social capital of an individual allows him to use the resources of friends, relatives and acquaintances. The social capital of a society unites its members and creates conditions for the achievement of common goals by them. Similarly, the social capital of an enterprise is a factor of its competitiveness and profitability. And this means that the competitiveness and profitability of an enterprise can be influenced by managing its social capital. Formation of the sound decisions on managing the social capital of an enterprise is a complex process that can't be successfully implemented without applying economic and mathematical methods and models. This article is aimed at solving one of the urgent problems of creating analytical support for the management of social capital of enterprises - the formation of theoretical bases for modeling the influence of the external social capital of an enterprise on the decision of its stakeholders.

\section{The object of research and its technological audit}

The object of research is the processes of managing the social capital of the enterprise. For effective implementation of these processes, it is necessary to have mathematical models that will allow to evaluate the impact of both internal and external social capital of an enterprise on the future results of its activities. Today, the theoretical basis for constructing such models is not sufficiently developed, especially regarding the formalization of external social capital. Existing mathematical models (for example, [1-3]) describe the statistical dependencies between the components of external social capital and the initial performance of enterprises, without revealing the logic of this relationship. Therefore, in this article, let's use the method of simulation modeling, reproducing the logic of the influence of external social capital of enterprises on their activities.

\section{The aim and objectives of research}

The aim of research is development of a theoretical framework for modeling the impact of the characteristics of the external social capital of an enterprise on the decision of its stakeholders on the parameters of interaction with this enterprise.

Research objectives:

1. To determine what characteristics of the external social capital of an enterprise affect the decision of its arbitrary stakeholders.

2. To form a common decision-making problem (DMP) for arbitrarily selected stakeholders to choose the parameters of its interaction with the enterprise and to analyze how the characteristics of the external social capital of the enterprise affect the decision of this law.

3. To form an approach to simulation modeling of the influence of the external social capital of an enterprise on the decision of its stakeholders.

\section{Research of existing solutions of the problem}

External social capital of the enterprises is the network of relations of this enterprise with its external stakeholders (suppliers, buyers, partners, end-users, local social environment) [4-10].

Analysis of modern scientific developments has shown that statistical methods -correlation-regression and factor analysis are the main tools for investigating the relationship between the external social capital of enterprises and the results of their activities. In such studies, a group of 
enterprises is analyzed, each of which acts as a «black box», whose «inputs» are certain indicators of external social capital, and «outputs» - performance indicators under environmental conditions, realized in the past. This approach allowed scientists to discover various types of statistical dependence between the components of external social capital and the initial performance of enterprises. For example, in [1], the effect on the life chances of enterprises of the characteristics of their position in the network of technological innovation is investigated (studies were conducted for the enterprises of the semiconductor industry). In [2], the dependence of the success of new firms (start-ups) on the parameters of the composition and configuration of their alliances with other firms is revealed. In [3], latent components of external social capital (such as information diversity, information saturation, volume of information) are found and their impact on sales volumes of steel industry enterprises is analyzed.

Statistical methods in the above-mentioned studies give interesting and useful results. But in order to support decision-making on the management of the company's external social capital, it is necessary to develop an alternative approach - the content modeling approach based on the logic of the «transparent box», that is, it suggests the disclosure of the mechanism, content, structure of the phenomenon under consideration. This approach has not been extended to the studies of the external social capital of enterprises, although its application would allow to investigate the relationship of elements of external social capital and the decisions of stakeholders that affect the results of the enterprise's activity, under different variants of controlled impacts and environmental conditions. This fact determines the aim of the article.

\section{Methods of research}

The research uses the method of normative decision theory, which consists in formalizing the choice situations in which the subjects are in the form of decision-making problems.

\section{Research results}

6.1. Characteristics of external social capital. Social capital (including external) is «the totality of relationships that cause actions» [7]. Thus, the social capital of an individual generates certain actions beneficial to him from his acquaintances, colleagues and relatives. Social capital of a society generates certain actions of its members, which contribute to the achievement of the common good. Similarly, the external social capital of an enterprise generates certain actions of its stakeholders. In other words, it affects the decision of stakeholders on their interaction with this enterprise.

Let's determine what characteristics of the external social capital of an enterprise affect the decision of its arbitrary stakeholders.

There are three dimensions of characteristics of social capital: structural, cognitive and relational [8]. Structural characteristics of social capital reflect the properties of the network of relations as a whole, that is, characterizes the overall structure of the links between the subjects. Cognitive social capital is manifested in joint ideas, values and beliefs that promote cooperation and trust. The relational characteristics of social capital describe the characteristics of relations between subjects.

To identify the relational characteristics of the external social capital of an enterprise, it is first necessary to answer the question: what is the «relationship» between the enterprise and its stakeholders?

The relationship between the enterprise and the stakeholders is a kind of social relationship. In modern sociology, «social relations» are defined as an established system of normalized interactions between individuals, their groups, organizations and communities about something that connects them (values, subject, interest, etc.) [9]. The behavior of the subjects of relations is determined by formal and informal norms (that is, rules of conduct within the framework of relations), and also by mutual expectations. If expectations become stable, they become norms of interaction. Norms and expectations are determined by the content (form) of social relations. Max Weber gives examples of the content of social relations: struggle, enmity, love, friendship, respect, market exchange, rivalry of economic or any other nature [10]. The main forms of economic relations are partnership (cooperation) and competition (rivalry) [11].

From the above-mentioned description of social relations it turns out that the decision of subjects is influenced by such basic characteristics of their relations: the form of relations, norms and expectations. Then the relationship of arbitrary stakeholders with the enterprise, which are considered as a component of the external social capital of the enterprise, can be formally described by a tuple, where:

$R_{1}$ - the form of relations of these stakeholders with the enterprise (for example, the relationship between buyers and suppliers can exist in the forms of opportunism, coordination, cooperation or partnership);

$R_{2}$ - norms of behavior of the subjects of relations, fixed by agreements between the stakeholders and the enterprise;

$R_{3}$ - stakeholder expectations on the further behavior of the analyzed enterprise.

6.2. Approach to modeling the influence of the external social capital of an enterprise on the decision of its stakeholders. In order to simulate the influence of the external social capital of an enterprise on the decision of its stakeholders, let's apply the tools of the normative theory of decision-making. Within the framework of this theory, the different choice situations in which the subjects turn out are formalized in the form of standard decision-making problems (DMP).

The task of decision-making on the choice by arbitrary stakeholders of the parameters of its interaction with the analyzed enterprise is formalized as a pair $\langle A, K\rangle$, where $A=\left\{a_{i} \mid i \in I\right\} \quad-$ a lot of alternatives, which can be:

a) options for interaction parameters of stakeholders with the analyzed enterprise (the consumer determines the volume of the order of the products, the supplier determines the duration of the deferral of payments for materials, etc.);

b) options for enterprises, among which stakeholders choose their counterparties (the consumer chooses a supplier, the supplier chooses a partner, the contractor chooses a subcontractor).

$K$ - the principle of optimality, which reflects the preferences of stakeholders on a variety of alternatives. It can be described by a vector of particular criteria and 
a certain utility function that allows to «collapse» this vector into a scalar.

An alternative $a^{\text {opt }}$ is optimal in the above task $\langle A, K\rangle$ that meets the following conditions:

$$
a^{o p t}=\arg \max _{i \in I} u_{i}
$$

$$
u_{i}=u\left(v_{i}\right)
$$

where $u_{i}-$ a scalar estimate characterizing an alternative according to a set of partial criteria, taking into account the preferences of stakeholders; $u$ - utility function describing the preferences inherent in stakeholders in the multi-criteria choice situation considered; $v_{i}-$ a vector of estimates of the alternative by special criteria. For example, in [12] the following groups of particular criteria for customers' evaluation of their suppliers are identified: price, quality, supply, flexibility. Starting from this, it is possible to single out general groups of particular criteria for evaluation of arbitrary stakeholders from the set by arbitrary stakeholders:

1) price characteristics of the interaction of stakeholders with the enterprise (product prices, material prices, payment of subcontractor's works);

2) qualitative characteristics of the interaction of stakeholders with the enterprise (product quality, quality of service, what materials);

3 ) the timeframe for the enterprise to fulfill its obligations (for customers - the time of delivery of products, for suppliers - the timing of the company's calculations for received materials, for credit institutions - the duration of the delay in repayment of the company's loan obligations);

4) flexibility of the enterprise in matters of interests of stakeholders. Let's investigate how the characteristics of the external social capital of an enterprise - the form of relations, norms of behavior and expectations of stakeholders affect the solution of the problem $\langle A, K\rangle$.

The following conclusions regarding their impact on future decisions of arbitrary stakeholders are made on the basis of the content of the characteristics of considered relations:

1. The type of relationship affects the formulation of the problem of decision-making by stakeholders - a set of acceptable alternatives and the kind of evaluation function. For example, in the context of opportunistic relations, the appraisal function will reflect the short-term interest of stakeholders, and many alternatives may contain options for stakeholder actions that are contrary to the interests of the analyzed enterprise. At the same time, in the framework of partnerships, the valuation function reflects an assessment of the long-term benefits of stakeholders, and many alternatives contain options for stakeholder actions that are acceptable to both counterparties.

Let's note that the forms of relations between the enterprise and the stakeholders are determined by decisions of strategic management.

2. Norms of behavior of subjects of relations also affect the set of acceptable alternatives. At the same time, the strategic norms of relations affect many options for tactical actions, and tactical norms - on the many options for operational actions of stakeholders. For example, tactical norms of partnerships of the enterprise with the client may provide for a certain restriction on the volume of the minimum order of the client.

3. The expectations of stakeholders on the company's future behavior affect the evaluation of alternatives that describe the options for interaction of these stakeholders with the analyzed enterprise. The reason for this influence is the problem of limited information available to the stakeholders of the enterprise. Indeed, at the time of taking decisions on interaction with the analyzed enterprise (for example, decisions on ordering products, establishing partnerships, organizing cooperation), stakeholders do not have accurate information about the quality characteristics, compliance with the timing and flexibility of the enterprise's activities in the framework of this interaction. Let's note that the actual values of these characteristics can often differ from the values declared by the enterprise. The reasons are as follows:

- the quality characteristics, compliance with the timing and flexibility of the company's activities (in contrast to price characteristics) are affected by a number of unmanageable environmental factors, and therefore their actual values may deviate from the declared values due to the presence of problems in the activities of the enterprise; - evaluation of qualitative characteristics is subjective, and therefore qualitative assessments by stakeholders may differ from those of the enterprise;

- some information about these characteristics can be deliberately hidden by the enterprise.

Due to these reasons, stakeholders are forced to rely on their own predictions of quality characteristics, compliance with the timing and flexibility of the enterprise - waiting. That is, the expectations of stakeholders regarding the behavior of the analyzed enterprise are arguments of the valuation function instead of the characteristics of the interaction of stakeholders with the enterprise, which are unknown at the time of decision-making.

The expectations of stakeholders are formed on the basis of their own experience of interaction with the analyzed company, information about the experience of others, advertising materials and information from competent experts (for example, information on the availability of an ISO 9000 certificate).

Taking into account the foregoing, the assessments of alternatives to tasks are specified:

$$
u_{i}=u\left(v_{i}, o_{i}\right),
$$

where $v_{i}$ - the vector of the values of the characteristics of the alternative $a_{i} \in A$, which are known at the time of the decision (such are the price characteristics of stakeholder interaction with enterprises); $o_{i}$ - the vector of expected values of the characteristics of the alternative $a_{i}$, which are unknown at the time of the decision (these characteristics include quality characteristics, compliance with the timing and flexibility of the relevant enterprises).

As we can see, such characteristics of the enterprise's relations with stakeholders, as a form of relations, norms of behavior and stakeholder expectations, influence the formulation of the task of selection and decision of stakeholders on the parameters of their interaction with this enterprise. The availability of the enterprise resources and the effectiveness of its work depend on the decisions of stakeholders (Fig. 1). 


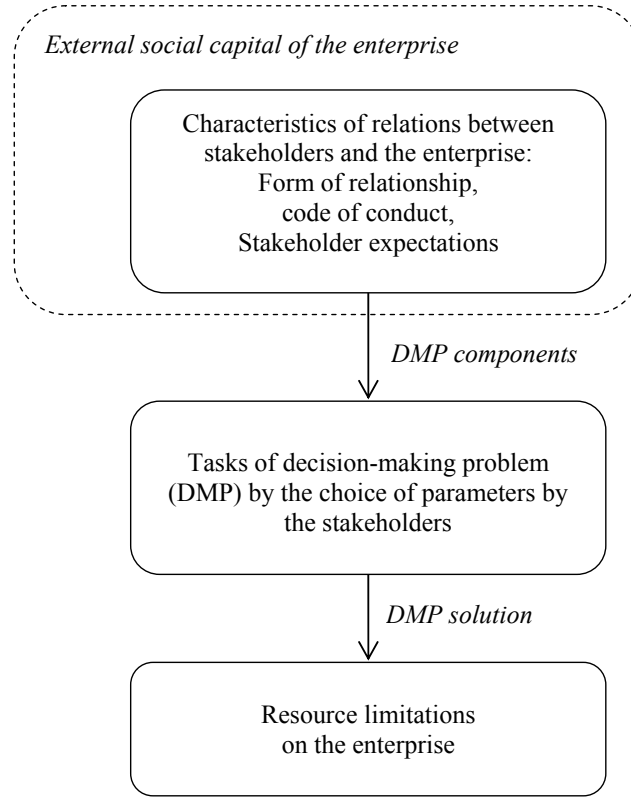

Fig. 1. The scheme of influence of the external social capital of the enterprise on the further activity of this enterprise (developed by the author

It is important that the above mentioned characteristics of the relations of an enterprise can and should influence. The existence of models of communication between the external social capital of the enterprise and the decisions of its stakeholders will make it possible to manage the relations of the enterprise more justifiably.

Proceeding from the above, it is possible to propose an approach to the simulation modeling of the influence of the external social capital of an enterprise on the decision of its stakeholders, based on the construction of formalized decision-making tasks that describe the choice situations in which the stakeholders are located. This approach has the following content:

1. Simulation of the dynamics of the characteristics of the relationship between the enterprise and each homogeneous group of stakeholders is carried out. The dynamics of the form of relations, the norms of relations and, first of all, the expectations of stakeholders are modeled.

2. Depending on the current characteristics of the relationship between the enterprise and the stakeholders, for each homogeneous group of stakeholders, the components of the decision-making task are selected to select the parameters for their interaction with the analyzed enterprise.

3. The decisions of each decision-making problem are calculated and on this basis the future parameters of stakeholder interaction with the analyzed enterprise are determined.

4. Resource limitations for the future activity of the enterprise are calculated.

\section{SWOT analysis of research results}

Strengths. The strength of the proposed approach is that it allows one to investigate the influence of the characteristics of the external social capital of an enterprise on the decision of its stakeholders under different variants of controlled impacts and environmental conditions.
Weaknesses. The weaknesses of the proposed approach are related to the complexity of constructing utility functions that describe the preferences of enterprise stakeholders.

Opportunities. The offered approach creates theoretical bases of construction of simulation models of activity of the enterprises taking into account their relations with stakeholders.

Threats. The threats of the decision-making process by the enterprise stakeholders may become an obstacle to the proposed approach.

\section{Conclusions}

1. The basic relational characteristics of the external social capital of the enterprise are determined, which influence the decision of the stakeholders of the given enterprise: these are the forms of relations between the enterprise and its stakeholders; Norms of behavior within the framework of these relations, as well as the expectations of stakeholders on the further behavior of the analyzed enterprise.

2. The influence of the relational characteristics of the enterprise's external social capital on the decision of the task of choosing arbitrary stakeholders for the parameters of its interaction with the analyzed enterprise is investigated.

3. An approach is proposed for modeling the influence of external social capital on enterprise activity, based on the logic of the «transparent box». This approach includes:

1) the construction of models for the adoption of decisions by stakeholders on the parameters of their interaction with the enterprise;

2) taking into account such characteristics of the relations between enterprises and stakeholders, as a form of relations, norms and expectations.

The proposed approach is intended for application in simulation models of enterprises' activities taking into account their relations with stakeholders. Such models are in demand in conditions of formation of the postindustrial economy, when the importance of non-material factors of enterprise competitiveness grows, including the relations between enterprises and stakeholders.

To implement the proposed approach it is necessary empirical research aimed at identifying the patterns of the formation of expectations and preferences of different groups of stakeholders of enterprises.

\section{References}

1. Podolny, J. M. Networks, Knowledge, and Niches: Competition in the Worldwide Semiconductor Industry, 1984-1991 [Text] J. M. Podolny, T. E. Stuart, M. T. Hannan // American Journal of Sociology. - 1996. - Vol. 102, № 3. - P. 659-689. doi:10.1086/230994

2. Baum, J. A. C. Don't go it alone: alliance network composition and startups' performance in Canadian biotechnology [Text] / J. A. C. Baum, T. Calabrese, B. S. Silverman // Strategic Management Journal. - 2000. - Vol. 21, № 3. P. 267-294. doi:10.1002/(sici)1097-0266(200003)21:3<267::aidsmj89>3.0.co; $2-8$

3. Koka, B. R. Strategic alliances as social capital: A multidimensional view [Text] / B. R. Koka, J. E. Prescott // Strategic Management Journal. - Vol. 23, № 9. - P. 795-816. doi:10.1002/smj.252

4. Baporikar, N. Handbook of Research on Entrepreneurship in the Contemporary Knowledge-Based Global Economy [Text] / 
N. Baporikar // Advances in Business Strategy and Competitive Advantage. - Hershey, PA: IGI Global, 2016. - 607 p. doi:10.4018/978-1-4666-8798-1

5. Westlund, H. Social Capital in the Knowledge Economy: Theory and Empirics [Text] / H. Westlund. - Berlin, Heidelberg: Springer-Verlag, 2006. - 212 p. doi:10.1007/978-3-540-35366-9

6. Belkin, V. N. Sotsial'nyi kapital organizatsii [Text] / V. N. Belkin, N. A. Belkina, O. A. Antonova, V. Yu. Vinogradova // Cheliabinskii gumanitarii. - 2009. - № 3 (9). - P. 34-40.

7. Radaev, V. Term of Capital, Forms of Capitals and their Conversion [Text] / V. Radaev // Journal of Economic Sociology. - 2002. - № 4 (3). - P. 20-32.

8. Nahapiet, J. Social capital, intellectual capital, and the organizational advantage [Text] / J. Nahapiet, S. Ghoshal // Academy of Management Review. - 1998. - Vol. 23, № 2. - P. 242-266. doi:10.5465/amr.1998.533225

9. Kandaurova, A. V. Structure of social interaction [Text] A. V. Kandaurova // Bulletin Of Nizhnevartovsk State University. - 2013. - № 4. - P. 62-66.

10. Veber, M. Osnovnye sotsiologicheskie poniatiia [Text] / M. Veber // Sotsiologicheskoe obozrenie. - 2008. - № 2 (7). P. $89-127$.

11. Pozniakov, V. P. Business partnership as one of forms of business activity of businessmen [Text] / V. P. Pozniakov, T. S. Vavakina // Knowledge. Understanding. Skill. 2009. - № 4. - P. 36-43.
12. Cousins, P. Strategic Supply Management: Principles, Theories and Practice [Text] / P. Cousins, R. Lamming, B. Lawson, B. Squire. - Prentice Hall: Harlow, 2008. - 336 p.

\section{РАЗРАБОТКА ПОДХОДА К МОДЕЛИРОВАНИЮ ВЛИЯНИЯ ВНЕШНЕГО СОЦИАЛЬНОГО КАПИТАЛА ПРЕДПРИЯТИЯ НА РЕШЕНИЯ ЕГО СТЕЙКХОЛДЕРОВ}

Предложен подход к имитационному моделированию влияния внешнего социального капитала предприятия на его деятельность на основе моделирования процесса принятия решений стейкхолдерами этого предприятия. Данный подход предполагает построение формализованных задач принятия решений, описывающих ситуации выбора, в которых находятся стейкхолдеры и настройке параметров этих задач в зависимости от определенных характеристик отношений между стейкхолдерами и рассматриваемым предприятием.

ключевые слова: внешний социальный капитал предприятия, отношения предприятия со стейкхолдерами, ожидания стейкхолдеров, моделирование решений стейкхолдеров.

Potrashkova Lyudmyla, PhD, Associate Professor, Department of Computer Systems and Technologies, Simon Kuznets Kharkiv National University of Economics, Ukraine, e-mail: LV7@ukr.net, ORCID: http://orcid.org/0000-0002-8239-2794 